\title{
Kinetics of copper desorption from soils as affected by different organic ligands
}

\author{
*E. A. Elkhatib; A. M. Mahdy; M. E. Saleh; N. H. Barakat
}

Department of Soil and Water Science College of Agriculture, Alexandria University, Alexandria, 21545, Egypt

\author{
Received 21 April 2007; revised 15 May 2007; accepted 5 June 2007; available online 20 June 2007
}

\begin{abstract}
Desorption of $\mathrm{Cu}$ and low molecular weight dissolved organics are the primary factors that impact fate and transport of $\mathrm{Cu}$ in soils. To improve predictions of the toxicity and threat from $\mathrm{Cu}$ contaminated soil, it is critical that time-dependent desorption behavior be understood. In this paper, the effect of organic ligands citrate, malate, and succinate on the kinetics of $\mathrm{Cu}$ desorption from contaminated soils varying widely in soil characteristics was investigated at $25^{\circ} \mathrm{C}$ and the soils used were referred to as clay, calcareous and sandy soils. The amount of $\mathrm{Cu}$ released by the used organic ligands varied greatly with physicochemical properties of the soils. The rate of $\mathrm{Cu}$ release by different extractants was in the order citric $>$ malic $>$ succinic, which was consistent with the stability constants of $\mathrm{Cu}$ complexes with these ligands. The modified Freundlich and the Elovich and Parabolic diffusion models were used to describe dsorption of $\mathrm{Cu}^{2+}$ from the three studied soils as affected by the organic ligands. All of the models fit the data well with correlation coefficients ranging from 0.83 to $1.00(\mathrm{P}<0.01)$. Each Model has a set of assumptions for the different physical and chemical properties of the systems to which they are being applied. The uses of these equations yield different magnitudes for the calculated variable, but the relationships between the soil + organic ligands and their effect (i.e., increase or decrease) on these variables are the same. Such information is critical, since $\mathrm{Cu}$ is used in a variety of industrial and manufacturing processes and is one of the most common contaminants found at hazardous waste sites.
\end{abstract}

Key words: Copper, kinetics, desorption, organic ligands

\section{INTRODUCTION}

Copper enters agricultural ecosystems through applications of $\mathrm{Cu}$-containing fungicides, stable manures, and liquid or solid wastes from $\mathrm{Cu}$-related mining and manufacturing. The accumulated $\mathrm{Cu}$ concentrations in agricultural soils have reached 110 to $1500 \mathrm{mg} / \mathrm{kg}$, compared with 20 to $30 \mathrm{mg} / \mathrm{kg}$ background levels (Baker, 1990). Because copper is considered as a hazardous metal and is included in the EPA's list of priority pollutants, the USEPA and the European union have established maximum copper limits for soil and for biosolids to be applied to fields. The current soil cleanup criteria for $\mathrm{Cu}$ in the USA is $600 \mathrm{mg} / \mathrm{kg}$ (USEPA, 1999), and the upper limit of total soil $\mathrm{Cu}$ set by the European Union for receiving $\mathrm{Cu}-$ containing sewage sludge is $140 \mathrm{mg} / \mathrm{kg}$ (Ministry of Agriculture, Fisheries and Food,1993). Fate and bioavailability of metals in soils are controlled by three main processes: (i) removal of metals from the soil solution by sorption onto soil particles, (ii) release of the metal from the soil particle to the soil solution

«*Corresponding Author Email: selkhatib1@yahoo.com

Tel.: +2 0359 04684; Fax: +2 035904684 (desorption), and (iii)precipitation-dissolution of the metal as an independent phase in the soil matrix (Sposito, 1989; Sparks, 2003). However, researchers often rely on maximum adsorption levels and neglect desorption behavior to predict the fate and transport of contaminants such as $\mathrm{Cu}$ in the environment. This is unfortunate since once a soil is contaminated, desorption is an important process that controls the bioavailability of the contaminant. Thus, in order to improve remediation strategies, risk assessments, and make better predictions about the mobility of contaminants, it is critical that time-dependent metal desorption behavior on soil be understood. Lowmolecular-weight organic acids originated from decomposition of soil organic matter in the upper soil horizons play an important role in the fate of metals (Glover, et al., 2002; Collins, et al., 2003). The anions of Low-molecular-weight organic acids can form soluble complexes with metal cations (Stevenson and Fitch, 1981), and modify the fixation of metals by soil organic matter, oxides, clays, and enhance their release (Chen, et al., 2003). There were several reports on the effect of 
organic ligands on adsorption of metals ( $\mathrm{Wu}$, et al., 2003), however, very little information about the effect of organic ligands on desorption of copper are available. In this study, therefore, we have investigated the effect of three different organic ligands on copper desorption behavior of selected Egyptian soils varying widely in chemical characteristics. Information obtained from this studywill give insights to scientists and engineers that may lead to improved remediation strategies, disposal practices, and risk assessments.

\section{MATERIALS AND METHODS}

\section{Soils}

Samples of three surface soils $(0-30 \mathrm{~cm})$ which differed in location, origins, texture and calcium carbonate content were used. One was a clay alluvial soil (Torrifluvents), the second was a calcareous soil (Calciorthids) and the third was a sandy loam desert soil (Quartzipasmment). Hereafter, the soils will be referred to as clay, calcareous and sandy soils respectively. The soils were air-dried, passed through a 2- $\mathrm{mm}$ sieve and stored in plastic bags before use. The $\mathrm{pH}$ values of the soils were measured in a 1:2 soilwater, conductivity (EC) was measured in the soil paste extracts. The organic matter content was determined by the method of Walkley and Black (Nelson and Sommers, 1982) and the cation exchange capacity by the method of Thomas (1982). Particle size analysis was determined by the hydrometer method (Black, 1965). Selected chemical and physical properties of the three soils studied are shown in Table 1.

\section{Organic acids}

Organic acids that occur naturally in soils and differ in number of functional groups were selected for the study. The selected organic acids are citric, malic and succinic. Table 2 lists some of the characteristics of the organic acids.

Table1: Selected chemical and physical characteristics of the three soils

\begin{tabular}{lcccccccc}
\hline Type of soil & $\mathrm{pH}$ & $\begin{array}{c}\text { E.C } \\
\mathrm{dS} / \mathrm{m}\end{array}$ & Clay & Silt & $\begin{array}{c}\text { Sand } \\
\mathrm{kg} / \mathrm{g}\end{array}$ & $\begin{array}{c}\text { Total } \\
\text { Carbonate }\end{array}$ & $\begin{array}{c}\text { Organic } \\
\mathrm{matter}\end{array}$ & $\begin{array}{c}\text { CEC } \\
\mathrm{cmol}\left(\mathrm{p}^{+}\right) / \mathrm{kg}\end{array}$ \\
\hline Clay & 8.40 & 0.75 & 446.00 & 140.00 & 419.00 & 30.00 & 14.00 & 33.00 \\
Calcareous & 7.90 & 4.54 & 268.00 & 64.00 & 449.00 & 260.00 & 2.10 & 18.00 \\
Sandy & 8.00 & 1.12 & 194.00 & 13.00 & 793.00 & 190.00 & 7.90 & 11.00 \\
\hline
\end{tabular}

Table 2: Relevant properties of low-molecular- weight organic acids used in the study

\begin{tabular}{llccc}
\hline Organic acids & Chemical formula & Molecular weight $(\mathrm{g})$ & Ligand form & $\mathrm{pk}_{\mathrm{a}}{ }^{*}$ \\
\hline Malic & $\mathrm{HO}_{2} \mathrm{CCH}_{2} \mathrm{CH}(\mathrm{OH}) \mathrm{CO}_{2} \mathrm{H}$ & 134.09 & $3.46,5.1$ & $\mathrm{H}_{2} \mathrm{~L}$ \\
Succinic & $\mathrm{HOOCCH}_{2} \mathrm{CH}_{2} \mathrm{COOH}$ & 118.09 & $\mathrm{H}_{2} \mathrm{~L}$ & $4.16,5.61$ \\
Citric & $\mathrm{C}(\mathrm{OH})(\mathrm{COOH})\left(\mathrm{CH}_{2} \mathrm{COOH}\right)_{2}$ & 192.13 & $\mathrm{H}_{3} \mathrm{~L}$ & $3.13,4.78,6.43$ \\
\hline
\end{tabular}

* $\mathrm{pk}_{\mathrm{a}}$ values were adopted from Serjeant and Dempsey (1979)

Table3: Kinetic modeling parameters and correlation coefficients for $\mathrm{Cu}$ desorption from the three studied soils as affected by different organic ligands at $298 \mathrm{~K}$

\begin{tabular}{|c|c|c|c|c|c|c|c|c|c|}
\hline \multirow[b]{2}{*}{$\begin{array}{l}\text { Organic } \\
\text { Ligands }\end{array}$} & \multicolumn{3}{|c|}{ Elovich } & \multicolumn{3}{|c|}{ Parabolic diffusion } & \multicolumn{3}{|c|}{ Modified Freundlich } \\
\hline & $\begin{array}{c}\mathrm{a} \\
{[\mathrm{mmol}} \\
\mathrm{Cu} / \mathrm{kg}]\end{array}$ & $\begin{array}{c}\alpha \\
{[\mathrm{mmol} \mathrm{Cu} /} \\
\mathrm{kg} / \mathrm{min}]\end{array}$ & $\mathrm{R}^{2 *}$ & $\begin{array}{c}\mathrm{K}_{\mathrm{d}} \\
{[\mathrm{mmol} \mathrm{Cu} / \mathrm{kg}]}\end{array}$ & $\begin{array}{c}\mathrm{a} \\
{[\mathrm{mmol} \mathrm{Cu} /} \\
\mathrm{kg} / \mathrm{min}]\end{array}$ & $\mathrm{R}^{2 *}$ & $1 / \mathrm{m}$ & $\begin{array}{c}\mathrm{K}_{\mathrm{d}} * 10^{3} \\
\min \end{array}$ & $\mathrm{R}^{2 *}$ \\
\hline \multicolumn{10}{|c|}{ Sandy soil } \\
\hline Malic & 1.15 & 2.22 & 0.950 & 2.51 & 0.19 & 0.833 & 0.22 & 1.53 & 0.946 \\
\hline Citric & 1.35 & 13.64 & 0.975 & 3.99 & 0.16 & 0.891 & 0.15 & 2.93 & 0.974 \\
\hline Succinic & 1.04 & 0.95 & 0.914 & 1.99 & 0.19 & 0.865 & 0.33 & 0.20 & 0.824 \\
\hline \multicolumn{10}{|c|}{ Calcareous soil } \\
\hline Malic & 1.16 & 1.98 & 0.966 & 2.40 & 0.19 & 0.830 & 0.23 & 1.33 & 0.939 \\
\hline Citric & 1.53 & 37.73 & 0.964 & 3.92 & 0.14 & 0.847 & 0.13 & 3.27 & 0.923 \\
\hline Succinic & 1.35 & 0.79 & 0.955 & $\begin{array}{l}1.33 \\
\text { Clay soi }\end{array}$ & 0.17 & 0.915 & 0.29 & 0.53 & 0.909 \\
\hline Malic & 1.10 & 1.47 & 0.925 & 2.47 & 0.14 & 0.865 & 0.22 & 1.13 & 0.798 \\
\hline Citric & 1.73 & 45.38 & 0.956 & 3.66 & 0.12 & 0.811 & 0.13 & 3.07 & 0.909 \\
\hline Succinic & 1.00 & 1.00 & 1.000 & 1.82 & 0.15 & 0.834 & 0.26 & 0.27 & 0.862 \\
\hline
\end{tabular}

All coefficient of determinations $\left(R^{2}\right)$ are significant at the $p=0.01$ level 
Kinetic experiments (Desorption)

Sub-samples of the soils were treated with $150 \mathrm{ug} / \mathrm{g}$ $\mathrm{Cu}$ as $\mathrm{CuSO} 4$. After adding $\mathrm{Cu}$, the soils were incubated at field capacity for $6 \mathrm{wks}$, during which the soils were subjected to four wet-dry cycles. After 6 weeks the soils were air dried, crushed to pass through a $2 \mathrm{~mm}$ sieve and stored in polyethylene bag for chemical analysis. Kinetic batch experiments were carried out by adding $10 \mathrm{~g}$ of contaminated soil samples to $40 \mathrm{~mL}$ of organic acid $(3 \mathrm{mM})$ in a reaction vessel unit. The mixtures were stirred and an aliquot of about $10 \mathrm{ml}$ was removed and filtered at selected time intervals $[5,10$, 20,40, 60,120,240,480 minute]. The filtrate was analyzed for $\mathrm{Cu}$ using atomic absorption spectrometry (AAS) and a number of different kinetic models were applied to describe the desorption. The kinetic experiments were carried out at $25^{\circ} \mathrm{C}$ temperatures. The samples were centrifuged for 15 minutes equilibration filtered, and $\mathrm{pH}$ was measured. Copper in the extract was determined using atomic absorption spectrometry (AAS).

\section{Kinetic modeling}

Three Kinetic Models were applied to the desorption data to better understand the effects of organic ligands and time on the desorption process. The three equations are as follows.

Elovich Equation (Chien and Clayton, 1980, Elkhatib and Hern, 1988)

$\mathrm{q}=(1 / \alpha) \ln (\mathrm{a} \alpha)+(1 / \alpha) \ln \mathrm{t}$

(1)

Where:

$\mathrm{q}=$ the amount of adsorbate released in time $\mathrm{t}$;

$\mathrm{a}=\mathrm{a}$ constant; and

$\alpha=$ a constant, related to the initial velocity of the reaction.

Thus a plot of q versus $\ln \mathrm{t}$ should give a linear

relationship with the slope of $(1 / \alpha)$ and intercept of $(1 / \alpha)$ $\ln (\mathrm{a} \alpha)$.

Parabolic diffusion equation (Laidler, 1965)

This equation may be written:

$\mathrm{q}=\mathrm{a}+\mathrm{k}_{\mathrm{d}} \mathrm{t}^{1 / 2}$

Where:

$\mathrm{q}=$ the amount of $\mathrm{Cu}$ desorbed in time $\mathrm{t}$.

$\mathrm{a}=\mathrm{a}$ constant.

$\mathrm{k}_{\mathrm{d}}=$ apparent diffusion rate coefficient.

Thus, a plot of " $q$ " $\mathrm{t}^{1 / 2}$ should provide a linear relationship if the reaction conforms to parapolic diffusion law.
Modified Freundlich Equation

The modified Freundlich equation (Kuo and Lotse, 1973) used in the form:

$\mathrm{q}=\mathrm{k}_{\mathrm{d}} \mathrm{C}_{\mathrm{i}} \mathrm{t}^{1 / \mathrm{m}}$

Where:

$\mathrm{q}=$ desorbed $\mathrm{Cu}(\mathrm{mmol} / \mathrm{kg})$

$\mathrm{C}_{\mathrm{i}}=$ initial $\mathrm{Cu}$ concentration $(\mathrm{Mm})$

$\mathrm{t}=$ reaction time $(\mathrm{min})$

$\mathrm{k}_{\mathrm{d}}=$ desorption rate coefficient $\left(\mathrm{min}^{-1}\right)$, and

$1 / \mathrm{m}=$ constant.

The parameter $\mathrm{k}_{\mathrm{d}} \mathrm{C}_{\mathrm{i}}$ and $1 / \mathrm{m}$ were calculated from the intercept and slope, respectively of the linear plots. These equations have been widely applied in desorption studies in soils and soil components, even though, the equations are empirical and yield only apparent rate parameters. Finding a meaningful model that can accurately describe these data is extremely difficult because of the heterogeneous nature of soil. Therefore, the use of these models in this study was only for qualitative comparison between soil and organic ligands combination.

\section{Statistical analysis}

All data were processed by Microsoft Excel (Microsoft, 2000), and the regression of linear and other statistical analyses were conducted using the programs of SAS Release 6.12 (SAS Institute, 1996).

\section{RESULTS}

Physicochemical properties of soils

Table 1 displays physical and chemical properties of the studied soils. Organic matter content is approximately $14,2.1$ and $7.9 \mathrm{~g} / \mathrm{kg}$ in clay, calcareous and sandy soils, respectively. The clay soil contains much less calcium carbonate percentage than the other two soils (calcareous soil samples had the highest). The clay soil samples display the highest CEC while sandy soil samples had the lowest (clay, 33; calcareous 18; and sandy $\left.11 \mathrm{cmol}\left(\mathrm{p}^{+}\right) / \mathrm{kg}\right)$.

\section{Copper desorption vs time}

The effect of time on desorption of $\mathrm{Cu}$ from the three studied soils by using different organic extractants is displayed in Fig. 1. A nearly linear relationship of $\mathrm{Cu}$ release versus time was observed in the soil samples studied for all the extractants (citric, malic, and sucinic acids). Desorption of $\mathrm{Cu}$ was least in clay soil while the sandy soil exhibited the highest release, copper extractability from calcareous soil was intermediate 
(Fig. 1). For the different soils, $\mathrm{Cu}$ desorption followed the release order: citric acid $>$ malic acid $>$ succenic acid.The sequence of amounts of $\mathrm{Cu}$ released by these ligands is generally in accord with the stability constants of $\mathrm{Cu}$ complexes with these ligands (Table 2). The percentage of $\mathrm{Cu}$ released from the surface of soil system is also consistent with the stability constants of the complexes of $\mathrm{Cu}$ with those ligands .Citrate ligands released $28 \%$ of added $\mathrm{Cu}$, about $23 \%$ of $\mathrm{Cu}$ added was released by malic acid while $19 \%$ was released by succinic acid (Table 2). The introduction of organic ligands to the desorption system may cause the change of the surface characteristics of soils, competitive distribution of metal ions between soil surface and organic ligands in the solution, and partly dissolution of minerals in soils. Overall, the release of $\mathrm{Cu}$ was greatly enhanced in the presence of citrate ligand under the reaction conditions we studied. To further assure the effectiveness of organic ligands on $\mathrm{Cu}$ release, the results were modeled using several kinetic equations.

\section{Kinetics}

The use of kinetic models was for qualitative comparison of data sets. Often, multiple models can fit the same set of kinetic data (Ogwada and Sparks, 1986); therefore, we have intended only to investigate the efficacy of these models in pointing out differences in $\mathrm{Cu}$ release trends. Table 3 gives the values of kinetic variables in the three equations applied to the experimental data.

\section{Elovich equation}

The empirical Elovich equation (Chein and Clayton, 1980) was used to describe the $\mathrm{Cu}$ desorption rate. Elovich equation plots of $\mathrm{Cu}$ desorbed vs. In of reaction time at $298 \mathrm{~K}$ for sandy, calcareous and clay soils as affected by citric, malic and succinic acid are shown in Fig. 2. A linear relationship exists between ' $q$ ' and 'Int' for each of the three organic acids used. Elovich equation parameters were determined from the slope and intercept of the linear plots. Parameters for the three soils and three organic acids are shown in Table (3). The " $\alpha$ " values listed in Table (3) for calcareous, sandy and clay soils were the highest in the presence of citric acid. In Elovich equation, a decrease in " $\alpha$ " in dicates a reduction in the desorption reaction rate (Chien and Clayton,1980) therefore the rate of $\mathrm{Cu}$ desorption from the soils studied increased as a result of using citric acid followed by malic acid and succinic acid .Correlation coefficients relating $\mathrm{Cu}$ released to $\mathrm{ln}$ reaction time are also given in table 3 . In all cases $\mathrm{R}^{2}$ values were significant at 0.01 level. Therefore, the Elovich equation appeared to be successful in describing the kinetics of $\mathrm{Cu}$ desorption from the studied soils as affected by the three organic ligands The Elovich equation (Eq.(2), fit all of the soil+ organic ligands samples $\left(r^{2}>0.914\right)$., The information provided by $\alpha$ suggested that the presence of citric acid will increase $\mathrm{Cu}$ desorption; however, these parameters are dependent on soil type and reaction conditions.
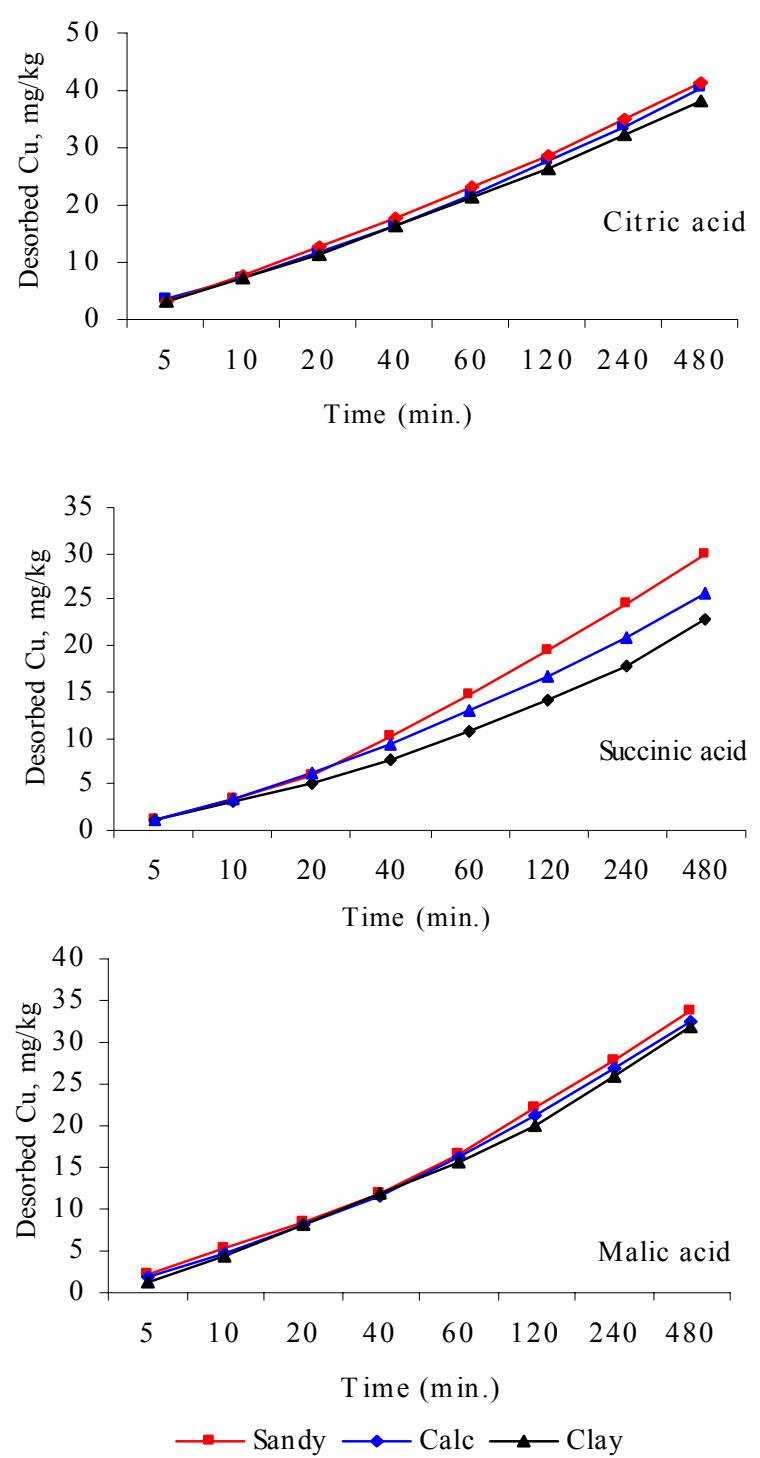

Fig. 1: Effect of different extractant and time on cumulative desorption of $\mathrm{Cu}$ from the three studied soils 

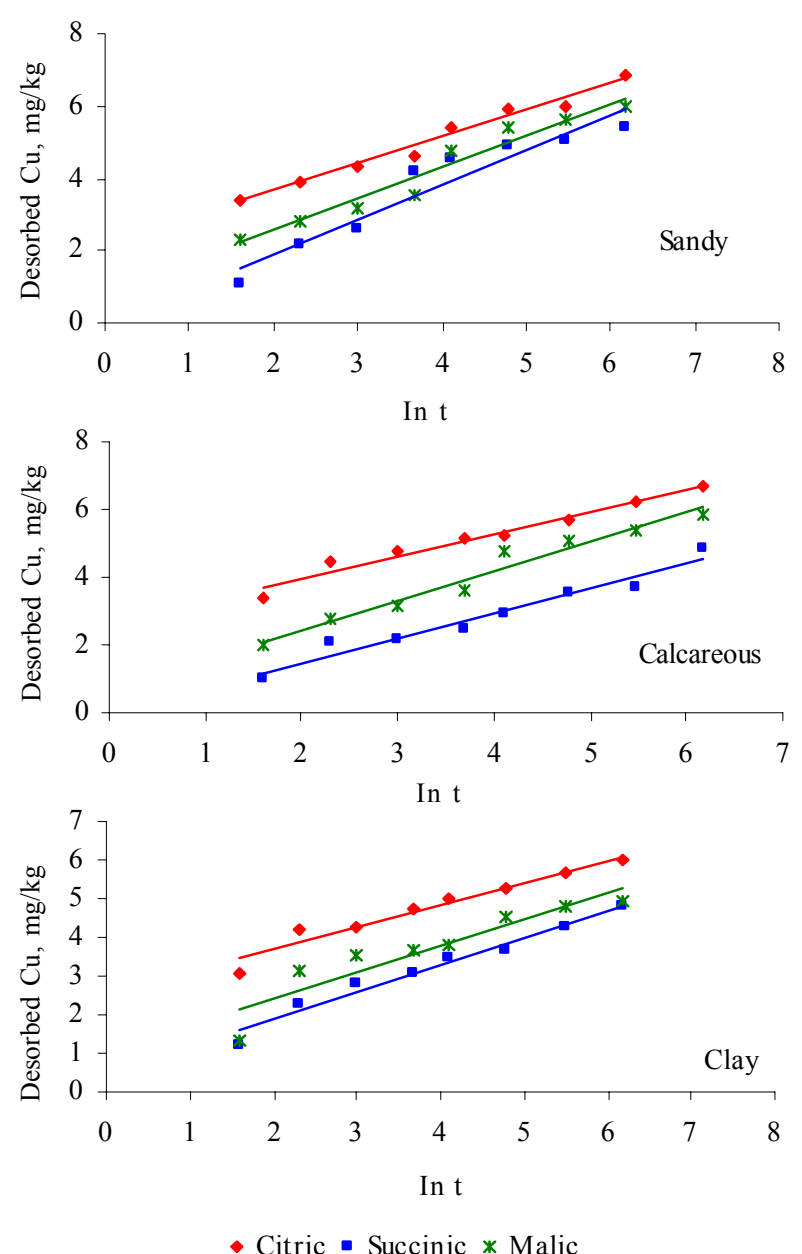

Fig. 2: Elovich equation plots for $\mathrm{Cu}$ desorption from the three studied soils as affected by different organic ligands

Parabolic diffusion equation (Laidler, 1965)

The Parabolic Diffusion Equation was also used to describe the kinetic data of $\mathrm{Cu}$ release. Parabolic Diffusion plots for $\mathrm{Cu}$ released from the soils as affected by three organic acids at $298 \mathrm{k}$ are shown in Fig. 3. Linear relationships exist between $\mathrm{Cu}$ released and $t^{1 / 2}$ for the three organic acids studied. Parabolic Diffusion law parameters were determined from the slope and intercept of the linear plots. Parameters of the three soils as affected by citric, succinic and malic acid are shown in Table (3). The apparent $\mathrm{Cu}$ diffusion rate coefficient " $\mathrm{k}_{\mathrm{d}}$ " in the parabolic diffusion law is considered a measure of the relative rate of $\mathrm{Cu}$ release. The " $k_{\mathrm{d}}$ " values were higher in the sandy soil than the values in the calcareous and clay soil. The " $\mathrm{k}_{\mathrm{d}}$ " values followed the trend sandy soil $>$ calcareous $>$ clay. The lower values in the clay soil are attributed to its higher organic matter, clay content and cation exchange capacity.

The " $k_{d}$ " values were also higher in the presence of citric acid in all the soil samples studied than the corresponding values in the presence of malic and succinic acids. Correlation coefficients relating $\mathrm{Cu}$ released to square root of reaction times were significant at 0.01 level in most cases and they are given in Table 3. Therefore, based on coefficient of determination, the parabolic diffusion law was also successful in describing the kinetics of $\mathrm{Cu}$ released by the three studied soils as affected by three organic ligands. The parabolic diffusion model (Eq. 1) seemed to best fit the sandy systems; however, linear relationships, an indicator that desorption processes 

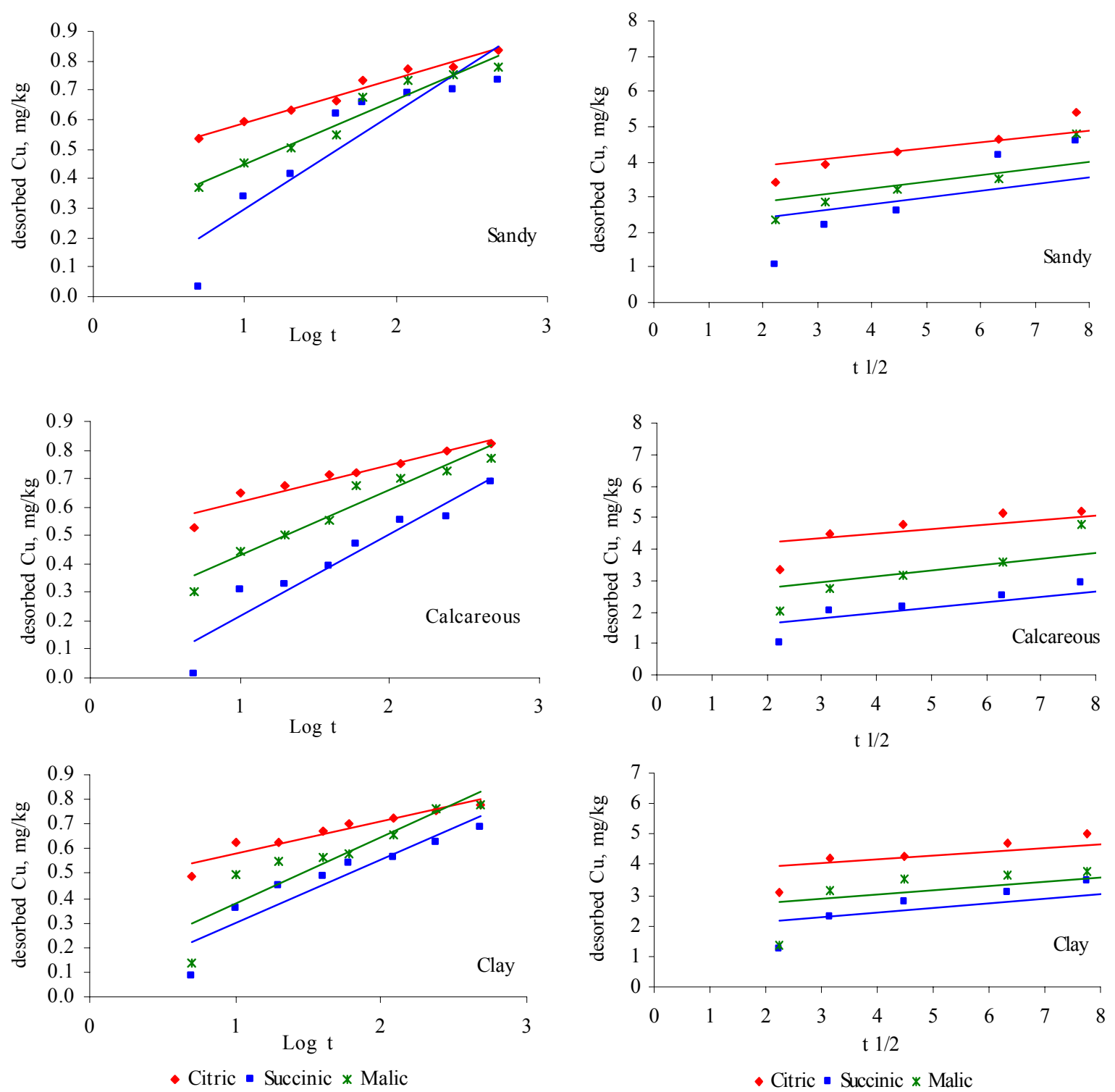

Fig. 3: Parabolic diffusion equation plots for $\mathrm{Cu}$ desorption from the three studied soils as affected by different organic ligands

are diffusion controlled (Toor and Bahl, 1999), are evident in the other two soils as well. The diffusion coefficient " $\mathrm{k}_{\mathrm{d}}$ " is greater in the soils with a light texture (sandy) and lower organic matter content, as soils with more heterogeneity are morelikely to have an increase in transport-limited processes. Calculated diffusion coefficients were higher for soil + citric acid, indicating that diffusion rates were faster. In the case of succinic acid, the diffusion coefficients were much lower; however, themodel still yields a straight line. Such an

Fig. 4: Modified freundlich equation plots for $\mathrm{Cu}$ desorption from the three studied soils as affected by different organic ligands

observation may suggest that diffusion influenced $\mathrm{Cu}$ desorption to a smaller extent than in the case of citric acid study, however, we cannot determine the type of diffusion that is taking place in either case.

\section{Modified freundlich equation}

The Modified Freundlich Equation (Kuo and Lotse, 1973) was also used to describe the $\mathrm{Cu}$ desorption data. Modified Freundlich plots of $\log \mathrm{Cu}$ desorbed vs. $\log$ of reaction time for the sandy soil, calcareous soil and 
clay soil at $298 \mathrm{~K}$ as affected by the three organic ligands are shown in Fig. 4. Linear relationships exist between $\log \mathrm{Cu}$ released and $\log \mathrm{t}$ for the three soil studied with three organic acids. The modified Freundlich equation parameters " $\mathrm{kdC}_{\mathrm{o}}$ " and " $1 / \mathrm{m}$ " were calculated from the intercept and the slope of the linear plots. The values of desorption rate coefficient " $\mathrm{k}_{\mathrm{d}} \mathrm{C}$ " and " $1 / \mathrm{m}$ " for the soils are shown in Table (3). In general, the desorption rate coefficient " $k_{d}$ " values listed in Table 3 as a result of citric acid addition were the highest in comparison with the succinic acid and malic acids in the same soil. Coefficient of determination relating $\log$ of $\mathrm{Cu}$ released to $\log$ of the reaction time are given in Table (3). In most cases, $\mathrm{R}^{2}$ values were significant. Therefore, based on coefficient of determination, the modified Freundlich equation was also successful in describing the kinetics of $\mathrm{Cu}$ release from the studied soils.

\section{DISCUSSION AND CONCLUSION}

A detailed investigation has been made to study the effect of time on desorption of $\mathrm{Cu}$ from three different soils by using different organic extractants. The quantity of $\mathrm{Cu}$ released from soils followed the trend Sandy $>$ Calcareous $>$ Clay. The low $\mathrm{Cu}$ desorption associated with the clay soil suggests that most $\mathrm{Cu}$ ions are specifically chemically sorbed by both organic matter and layer silicate clays. Organic matter at low levels (Alcacio, et al., 2001)has strong affinity for $\mathrm{Cu}$. McBride (1994) proposed possible binding configurations of $\mathrm{Cu}^{2+}$ on complexes of oxide minerals and organic matter: (i) $\mathrm{Cu}^{2+}$ is bonded to the mineral surfaces only (inner-sphere complex); (ii) $\mathrm{Cu}^{2+}$ is bonded to the organic matter that is adsorbed by the oxides at high levels (Type B ternary complex); and (iii) $\mathrm{Cu}^{2+}$ acts as a bridge cation between the oxides and the organic matter that is adsorbed at low levels (Type A ternary complex). The higher soil CEC generally coexisted with higher content of clay and organic matter, and showed strong ability on the sequestration of metals (Stewart, et al., 2003) and vice versa. The clay soil under study showed the highest values for organic matter, clay content and cation exchange capacity whereas sandy soils showed the lowest values of these properties (Table1). For all the studied soils, $\mathrm{Cu}$ desorption followed the release order: citric acid $>$ malic acid $>$ succenic acid. The difference in the effect on $\mathrm{Cu}$ desorption by organic acids is related to their chemical structures. Among the organic ligands used, ions of malic and citric acids carrying two or three-COO groups can form chelates with 5- or 6membered ring structure. These chelates are much more stable than succinate complexes. The greater stability of the citrate- and malate- $\mathrm{Me}^{\mathrm{z}+}$ complexes led to the greater efficacy of citric and malic acids in desorbing $\mathrm{Cu}$ from soils than succenic acid. Besides, succenic acid with a smaller acid dissociation constant $\left(\mathrm{pK}_{\mathrm{a}}\right.$ value 4.16) provided fewer anions for complexing with $\mathrm{Cu}$ than the other two acids ( $\mathrm{pK}_{\mathrm{a}}$ values 3.13 and 3.46), and thus may show a smaller effect on metal desorption. In addition, major forms of citric acid at high $\mathrm{pH}$ changed from $\mathrm{H}_{3} \mathrm{~L}, \mathrm{H}_{2} \mathrm{~L}$ ", and $\mathrm{HL}^{2 "}$ to $\mathrm{L}^{3 "}$. $\mathrm{HL}^{2 "}$ and $\mathrm{L}^{3 "}\left(\mathrm{~L}^{3 "}, \mathrm{HL}^{2 "}\right.$ and $\mathrm{L}^{3}$ "always showed greater chelating ability with heavy metals than $\mathrm{H}_{3} \mathrm{~L}$ and $\mathrm{H}_{2} \mathrm{~L}$ "), leading to larger desorption amount of $\mathrm{Cu}$, in the presence of $\mathrm{HL}^{2 "}$ and $\mathrm{L}^{3 "}$ than in the presence of $\mathrm{H}_{3} \mathrm{~L}$ and $\mathrm{H}_{2} \mathrm{~L}$ (Martell and Smith,1977). Data presented here show that organic ligands are effective chelators of sorbed metals and these ligands may play an important role in the mobilization and phytoavailability of $\mathrm{Cu}$ in soils. The empirical Elovich, the Parabolic Diffusion and the Modified Freundlich models were used to describe the $\mathrm{Cu}$ desorption rate. Based on coefficient of determination, the three models were all successful in describing the kinetics of $\mathrm{Cu}$ release from the studied soils. All of the models fit the data well, and each has a set of assumptions for the different physical and chemical properties of the systems to which they are being applied. The uses of these equations yield different magnitudes for the calculated variable, but the relationships between the soil + organic and their effect (i.e., increase or decrease) on these variables are the same. Information obtained from this studywill give insights to scientists and engineers that may lead to improved remediation strategies, disposal practices, and risk assessments.

\section{REFERENCES}

Alcacio, T.E.; Hesterberg, D.; Chou, W.Q.; Martin, J.D.; Beauchemin, S.; Sayers, D.E., (2001). Molecular scale characteristics of $\mathrm{Cu}(\mathrm{II})$ bonding in goethite-humate complexes. Geochim. Cosmochim. Acta., 65, 1355-1366.

Baker, D.E., (1990). Copper., B.J. Alloway (Ed.) Heavy metals in soils. Blackie and Sons Ltd., London. 151-176.

Black, C.A., (1965). Methods of soil analysis, Part 1. Agronomy, 9. Amer. Soc. of Agronomy, Madison, WI. 1-1572.

Chen, Y.X.; Lin,Q.; Luo, Y.M.; He, Y.F.; Zhen, S.J.; Yu, Y.L.; Tian, G.M.; Wong, M.H., (2003).The role of citric acid on the phytoremediation of heavy metal contaminated soil. Chemosphere. 50, 807-811. 
Kinetics of copper desorption from soils as affected by different...

Chien, S.H.; Clayton.W.R., (1980). Application of Elovich equation to the kinetics of phosphate release and sorption in soils. Soil Sci. Soc. Am. J., 44, 265-268.

Collins, R.N.; Merrington, G.; Mclaughlin, M.J.; Morel, J. L., (2003). Organic ligand and $\mathrm{pH}$ effects on isotopically exchangeable cadmium in polluted soils. Soil Sci. Soc. Am. J., 67, 112-121.

Elkhatib, E.A., Hern, J.L., (1988). Kinetics of phosphorus desorption from Appalachian soils. Soil Sci., 145, 11-19.

Glover, I.I., Eick, L.J.; Brady, M.J., (2002). Desorption kinetics of cadmium $^{2+}$ and lead ${ }^{2+}$ from goethite: influence of time and organic acids. Soil Sci. Soc. Am. J. 66, 797-804.

Kuo, S., Lotse, E.G., (1973). Kinetics of phosphate adsorption and desorption by hematic and gibbsite. Soil Sci. 116, 400406.

Laidler, K.J., (1965). Chemical kinetics $2^{\text {nd. }}$ Ed. McGraw Hill. New York.

McBride, M.B., (1994). Environmental chemistry of soils. Oxford Univ. Press, Oxford.

Martell, A.E.; Smith, R.M., (1977). Critical stability constants other organic ligands, 3, Plenum Press, New York.

Ministry of Agriculture, Fisheries and Food. (1993). Review of the rules for sewage sludge application to agricultural land: Soil fertility aspects of potentially toxic elements. Report of Independent Scientific Committee. PB 1561. MADD Publ., London.

Nelson, D.W.; Sommers. L.E., (1982). Total carbon, organic carbon and organic matter, In Methods of soil analysis, eds., page, A.L., Miller, R.H., and Keeney, D.R. American Soc. of Agronomy, Madison, Wisconsin, USA. 539-549

Ogwada, R.A.; Sparks, D.L., (1986). A critical evaluation on the use of kinetics for determining thermodynamics of ion exchange in soils. Soil Sci. Soc. Am. J., 50,300-305.
SAS Institute (1996). SAS Release 6.12. SAS Inst., Cary, NC. Serjeant, E.P.; Dempsey, B., (1979). Ionization constantsof organic acids in aqueous solutions.Pergamon.Oxford.

Sparks, D.L., (2003). Environmental soil chemistry. $2^{\text {nd. }}$ Ed. Academic Press, New York.

Sposito, G., (1989). The Chemistry of soils. New York: Oxford University Press.

Stevenson, F.J.; Fitch, A., (1981). Reactions with organic matter. p. 69-95. In Copper in soils and plants, Ed, Loneragan, J.F. et al .Academic Press, Sydney, Australia.

Stewart, M.A.; Jardine, P.M.; Barnett, M.O.; Mehlhoun, T.L.; Hyder, L.K.; Mckay, L.D., (2003). Influence of soil geochemical and physical properties on the sorption and bioaccessibility of chromium (III). J. Environ. Qual., 32,129137.

Thomas, G.W., (1982). Exchangeable cations, In Methods of soil analysis,eds, A.L., Miller, R.H. and Keeney, D.R. American Soc. of Agronomy, Madison, Wisconsin, USA. 159-165,

Toor, G.S.; Bahl, G.S., (1999). Kinetics of phosphate desorption from different soils as influenced by application of poultry manure and fertilizer phosphorus and its uptake by soybean. Bioresource Technology. 69,117-121.

USEPA. (1999).The EPA Region III risk-based concentration table. USEPA, Philadelphia, PA.

Wu, Z.H.; Gu, Z.M.; Wang, X.R.; Evans, L. and Guo, H.Y., (2003). Effect of organic acids on adsorption of lead onto montmorillonite, goethite and humic acid. Environ. Pollut. 121, 469-457.

\section{AUTHOR (S) BIOSKETCHES}

Elkhatib, E. A., Ph.D., professor in the Department of Soil and Water Sciences, College of Agriculture, ElShatby Alexandria University, Alexandria, 21545, Egypt. Email: selkhatib1@yahoo.com

Mahdy, A. M., Ph.D., assistant professor in the Department of Soil and Water Sciences, College of Agriculture, El-Shatby Alexandria University, Alexandria, 21545, Egypt. Email: amahdy73@yahoo.com

Saleh, M. E., Ph.D., professor in the Department of Soil and Water Sciences, College of Agriculture, ElShatby Alexandria University, Alexandria, 21545, Egypt. Email: msaleh@yahoo.com

Batakat, N. H., M.Sc., research assistant in the Department of Soil and Water Sciences, College of Agriculture, El-Shatby Alexandria University, Alexandria, 21545,Egypt. Email: nbarakat@yahoo.com

\section{This article should be referenced as follows:}

Elkhatib, E.A., Mahdy, A.M., Saleh, M. E., Batakat, N.H., (2007). Kinetics of copper desorption from soils as affected by different organic ligands. Int. J. Environ. Sci. Tech., 4 (3), 331-338 . 